\title{
A STRUCTURAL EQUATION MODEL LINKING INNOVATION AND KNOWLEDGE MANAGEMENT CAPABILITY TO IMPROVE ORGANISATIONAL CAPABILITY EFFICIENCY
}

\author{
J.S. Travern ${ }^{1}$, S. Naidoo2*, \& A. Rajcoomar ${ }^{1}$
}

\section{ARTICLE INFO}

\section{Article details}

Submitted by authors 16 Dec 2020

Accepted for publication 26 Jul 2021

Available online 31 Aug 2021

\section{Contact details \\ * Corresponding author naidoosu@unisa.ac.za}

\section{Author affiliations}

1 School of Business Leadership, University of South Africa, South Africa

2 Department of Operations Management, University of South Africa, South Africa

\section{ORCID® identifiers}

J.S. Travern

https: / /orcid.org/0000-0001-9634-5561

S. Naidoo

https://orcid.org/0000-0003-4284-516X

\section{A. Rajcoomar}

https://orcid.org/0000-0002-4730-4912

\section{DOI}

http: / /dx.doi.org/10.7166/32-2-2473
Organisations implementing homogeneous and intellectual resource organisational capabilities, such as innovation (INNO) and knowledge management capability (KMC), suffer from organisational capability inefficiencies that are caused by multiple influences. The purpose of the study was to develop a structural equation model (SEM) for the alignment of INNO and KMC that would assist organisations' managers to improve organisational capability efficiency (OCE) during implementation. Since very little consideration has been given to the analogous nature of INNO and KMC in either theory or practice, organisations have most often implemented these strategic initiatives in isolation or by using a departmentalised approach. A structured questionnaire was used and analysed, primarily by means of factor analysis, to contribute to the validation of the SEM. The findings revealed that organisations implementing INNO must consider KMC and align/synthesise them to attain OCE.

\section{OPSOMMING}

Organisasies wat homogene en intellektuele hulpbron organiseringsvermoë implementeer, soos innovasie en kennis bestuursvermoë, ly gereeld aan ondoeltreffendheid as gevolg van verskeie redes. Hierdie studie het 'n strukturele vergelykingsmodel ontwikkel vir die belyning van innovasie en kennis bestuursvermoë om die organisasies se doeltreffendheid tydens implementering te verbeter. Omdat daar beperkte inligting in die literatuur en in praktyk hieroor beskikbaar is, het organisasies hierdie strategiese inisiatiewe in isolasie implementeer. 'n Gestruktureerde vraelys is gebruik en ontleed, hoofsaaklik deur middel van faktoranalise, om by te dra tot die validasie van die strukturele vergelykingsmodel. Die bevindings toon dat die organisasies wat innovasie implementeer inderdaad kennis bestuursvermoë moet oorweeg en dié inisiatiewe moet belyn om organisatoriese doeltreffendheid te behaal.

In a knowledge-intensive and organisation-based economy, managers of organisations are increasingly adopting the strategic imperatives of innovation and knowledge management to improve products and services for service delivery and competitive edge. However, organisations implementing homogeneous capabilities (those that are similar or, some cases, identical) and intellectual resource (knowledge assets and expertise) organisational capabilities such as innovation (INNO) and knowledge management capability (KMC) suffer from inertia and a lack of understanding of the organisational capability inefficiencies that are caused by multiple influences, complex building blocks, and depleted organisational capability. Therefore the main purpose of this study was to examine whether organisational capability efficiency (OCE) is improved by aligning or synthesising organisational capabilities when implementing INNO and KMC in organisations. The theoretical aspects of knowledge management, INNO, KMC, OCE, strategic alignment, and organisational capability are discussed in the study. The main objective of the study was to synthesise INNO and KMC to assist managers in organisations to improve OCE during implementation. This study adopted a positivist research philosophy. The variables derived from the theory for this study were INNO, 
KMC, and OCE. An in-depth literature review was undertaken to develop the constructs for the conceptual research model. The study sought to answer the research questions that were developed from the theory.

- Is there an effective model of the link between each of the dimensions of INNO and KMC and the dimensions of OCE?

- How could organisational capabilities be synthesised when implementing INNO and KMC to improve OCE?

The variables were operationalised into definable measurable indicators, and a research survey instrument was used to measure the variables and operationalise the indicators to test the hypothesis. The SEM developed in the study shows the interrelationships between INNO, KMC, and OCE, offering insight into the aligned/synthesised implementation of INNO, KMC, and OCE. In terms of the research result, it is recommended that organisations implementing INNO consider KMC concepts and, where applicable, align/synthesise them with the appropriate INNO to prioritise implementation for the organisation and so attain OCE. It was found that aligning/synthesising INNO and KMC coherently allowed managers and practitioners to achieve cohesive implementation strategies, an optimised use of resources, a reduced redundancy of effort, improved investments, and access to scarce and skilled resources.

The remainder of the paper is organised to present a detailed literature review that identifies the key constructs (with a focus on the research problem), followed by the research methodology. The empirical results are presented and explained. The value of the findings is highlighted in the conclusions.

\section{LITERATURE REVIEW}

The dilemma facing an organisation, such as costly resources and the diversity of capabilities that are required when implementing homogenous initiatives such as innovation and knowledge management, is discussed. The alignment theory, and its positive aspects in theoretical frameworks, were reviewed. Factors that affect INNO, KMC, and OCE were identified. A SEM aligning KMC, INNO, and OCE was developed using the constructs that emerged from the literature.

\subsection{Innovation}

Godin [1] mentions that, from the early 1900s onwards, anthropologists, sociologists, historians, and economists began theorising about innovation, each from their own perspective. In the 20th century, innovation became a very popular concept, owing to its being a key source of organisational growth and profitability. There are various studies of types of innovation, such as organisational innovation, that cover the administrative and technical, product and process, and radical and incremental dimensions [2], [3]. Globalisation and the increase in knowledge-based organisations have increased the theoretical and empirical interest in the integration of innovation with other organisational disciplines, such as an organisation's strategy process [4] and knowledge management [5]. Furthermore, Dobni and Sand [4] present a framework that delineates the interdependency of innovation and strategy, and outlines the role of top management in constantly renewing the positioning of the organisation.

Accordingly, this framework offers guidance that business leaders could practise when incorporating innovation into their strategy process. Innovation is an antecedent of INNO, and knowledge management is expected to impact or influence all types of innovation ([5] [6]. Innovation is the knowledge practice that converts knowledge into new products and services [7]. Innovation has been also characterised as a practice that encompasses organisational learning, with a certain degree of ambiguity and intrinsic probability for transformation, based on people's expertise, technological advancements, and organisational cultural elements, thus necessitating the elucidation of problems during its enactment [8]. Innovation is sometimes described as the improvement and application of novel ideas by experts who engage in transactions over time with others in the organisation [9].

\subsection{Knowledge management}

Since 1990, knowledge management has no longer been purely a science of organisational management because of the prominence of technological and networking applications. Instead, it is a new science to which the world's most prominent global organisations have assigned paramount importance, and for which they have constantly made methods to improve efficient knowledge management available. This was imperative to allow practitioners to increase productivity and organisational innovations [10]. Many experts see knowledge management as closely related to innovation, which is the view of this paper; but it is more pertinent for organisational capabilities. 
According to Beijerse [11], knowledge management is about realising the strategic organisational goals that are ultimately inspired by incentives and by enabling knowledge workers to cultivate and enhance their capability to interpret data and information by consuming accessible sources of information, knowledge, ability, culture, character, personality, and feelings. This is enabled by advancing and providing meaning to data and information. In this paper, knowledge management is defined as a discipline, capability, or organisational practice that creates, shares, stores, interprets, and transforms information or knowledge from sources of experience, skills, repositories, technologies, experts, communities of practice, lessons learnt, and intellectual assets, thus enabling the environment to increase innovation and OCE [11], [12], [13].

\subsection{The relationship between innovation and knowledge management studies}

Academics such as Durmus-Őzdemir and Abdukhoshimov [14] have seen the benefits to organisations of observing the link between innovation and knowledge management. Moreover, a few studies have concentrated on the relationship between innovation and knowledge management, since knowledge and innovation are valuable assets that give an organisation a competitive advantage [14]. Likewise, DurmusÖzdemir and Abdukhoshimov [14] explore the mediating role of innovation in the effect of the knowledge management process on performance. Their research provides guidance on how organisations can manage their knowledge to attain competitive advantage, grounded in their innovation efforts. A study of Kör and Maden [13] examines the relationship between effective knowledge management processes and innovation categories in organisations. Supplementing the current research, that study, which was was knowledgecentric, concluded that knowledge management practices relate positively to innovativeness [13].

According to Kör and Maden [13], organisations must create, transform, and manage knowledge in order to maintain INNO. However, their study was limited to knowledge management process capability, and did not address resource-based and knowledge-based capabilities. Therefore it would be beneficial to see whether this relationship still exists when considering the additional variables of resource-based and knowledge-based capabilities. Their study was also limited only to the innovation initiative processes, and did not investigate how the KMC influences all of the innovation capabilities, such as strategic capability, ideation capability, implementation capability, and commercialisation capability [15].

Similarly, Slavkovic and Babic [16] analysed the effect of knowledge management on innovativeness. The findings of their study indicated that knowledge management is positively related to the diverse dimensions of organisational innovation - for example, process innovation and administrative innovation. Their study was restricted to the process capabilities of knowledge management and innovativeness, and did not address the resource-based and knowledge-based capabilities of the organisation. The study's findings revealed that enhancing the processes related to knowledge management also means highlighting innovation programmes in the organisation.

On the other hand, Wuryaningrat [17] examined how knowledge sharing could possibly be transformed into innovation capabilities. That study offered a better understanding of the prominence of knowledge sharing for enhancing absorptive capacity and innovation capabilities. In addition, Lin, McDonough, Lin and Lin [18] observed the effect of learning capability on innovation. The results of their study showed that the amalgamation of these practices has a greater effect on innovation. However, the study was restricted to the learning capability of knowledge management, and determined its impact on innovation. Podrug, Filipović and Kovač [9] distinguished knowledge sharing and an organisation's INNO in Croatian companies. The findings of their empirical research pointed to the enjoyment in helping others as an individual factor, top management support as an organisational factor, and information communication and technology (ICT) use as a technology factor as significantly influencing the knowledge-sharing processes of the organisation. The findings further suggested that the willingness of employees to share and gather knowledge enables an organisation to improve its INNO.

From a practical standpoint, the relationships between knowledge-sharing enablers, processes, and organisational INNO could offer a guide to how organisations can stimulate knowledge-sharing cultures to improve their innovation performance.

Martinez-Conesa, Soto-Acosta and Carayannis [19] provided insight into the internal and external antecedents of open innovation (OI) in the context of small and medium-sized enterprises (SMEs), with an emphasis on the role of KMC. The research evaluated the effect of internal factors on KMC; the impact of organisational and external factors - namely, KMC and environmental dynamism - on open innovation; and whether environmental dynamism moderates the relationship between KMC and open innovation. The findings of the research confirmed that information technology-supported operations and commitment- 
based human resource practices have a positive and significant effect on KMC. The study supported the notion that KMC plays a critical role in the implementation of innovation. However, the study did not address INNC and KMC in detail, nor did it consider how these strategic imperatives affect OCE.

Al-Hakim and Hassan [20] examined the associations among the core requirements of knowledge management implementation, innovation, and organisational performance. Interestingly, their research findings indicated that the core requirements of knowledge management implementation had a direct and positive effect on innovation. They also observed that a few empirical studies explored the relationship between knowledge management and innovation. This supports the idea of providing organisations with a better appreciation of the relationship between knowledge management and innovation, especially their capabilities, which was the focus of the study reported in that paper.

Some studies have confirmed the positive impact of knowledge management processes, practices, and infrastructure on innovation [21]. For instance, Shujahat, Sousa, Hussain, Nawaz, Wang and Umer [22] investigated the mediating role of knowledge worker productivity between knowledge management process and innovation. Their findings indicated that knowledge worker mediates between only two knowledge management processes, knowledge creation, and knowledge utilisation and innovation. The role of the knowledge worker in promoting knowledge management practices in the workplace has been restricted, since it relies heavily on an individual's capacity rather than on a composite of resource-based and knowledge-based capabilities that would enable the organisation to create, transform, store, retain, collaborate, and disseminate knowledge efficiently in real time for decision-making or the development of knowledge.

It is evident that many researchers have maintained thus far that the effective management of knowledge leads to organisational innovation. Moreover, some organisations view knowledge management as an important antecedent to adopting and implementing innovation, whereby knowledge improves engagement in innovation through creating, using, and collaborating on new ideas and exploiting the organisation's intellectual authority [23].

\subsection{Organisational capabilities}

Organisational capability academics have shown that the prominence of capabilities in organisations nowadays is considerably greater than it was previously because of the relatively open and varied bases of innovation that are now accessible to organisations [24]. According to Chung, Wang, Huang and Yang [7], organisations largely overlook internal factors such as organisational capabilities. Durmus-Özdemir and Abdukhoshimov [14] described organisational capabilities as a complex knowledge system that consists of the organisation's technology system, managerial system, and value system.

McKinsey [25] defined a capability as anything that an organisation does well that drives meaningful business results. McKinsey's survey explored which capabilities are most critical to a company's business performance and why they focus on the capabilities they do. It also asked executives how their companies create and manage training and skills-development programmes and how effective those programmes are in maintaining or improving on their priority capabilities. It is notable that the majority of companies do not focus on a specific priority capability for purely competitive reasons; most often, the reason is that the capability is part of their culture [25]. Further, some three-quarters of respondents do not think that their companies are good at building the capability that is most important. When senior executives are involved in setting the capabilities agenda, companies are more successful at aligning those agendas with the capability that is most important to performance and more effective at building the needed skills.

\subsection{Innovation and knowledge management, theory, and practice}

Martinez-Conesa, Soto-Acosta and Carayannis [19] argued that, when organisations implement innovation processes, there is a heightened possibility of disappointment in dealing with the dissimilar knowledge processes, since knowledge processes require integrative knowledge management. They further suggested that an organisation should want to reconfigure and realign its knowledge management capabilities with suitable changing environments - a point that supports the importance of the current study. The speed at which original products, processes, and services are accomplished forces competitive organisations to produce and implement fresh management practices, structures, and tools to adjust to the prevailing situations or the anticipated change [26]. In this sense, the capability to innovate [26] and to manage data, information, and knowledge [13] in a way that would provide OCE is central to the success of organisations. Therefore it is strategic to shape long-term advantages in relation to competitors [26]. 
It is quite apparent from the cited studies that increased research on innovation, knowledge management, INNO, and KMC, especially in the last two decades, has developed a number of concepts, frameworks, and models, and knowledge management can be seen as a strategy to foster innovation. Still, another viewpoint is that some experts may view organisational capability as important (and some as most important) for the success of knowledge management or innovation in the organisation [27]. However, there seems to be a limited amount of theory that has attempted to align INNO and KMC to assist organisations during implementation.

\subsection{The homogeneous behaviour of INNO and KMC}

As can be seen from the literature, the implementation capabilities of innovation and knowledge management can be seen as similar, or in some cases identical, therefore described as homogeneous. Nevertheless, many organisations that implement INNO and KMC do so using an isolated approach [23]. Besides, many theoretical studies confirm the multifaceted nature of innovation and knowledge management in organisations.

As a result, this has often created redundancy and overlap, and it sometimes even has a spiralling effect on organisational resources and capabilities [23], [28]. Therefore organisations need to recombine or align interrelated capability across domains [28]. As suggested by Lin et al. [18], organisations need to discover methods to combine practices and capabilities in ways that will enable the synthesis, exchange, and application of learned knowledge through employees in the organisation. Following the resource-based and knowledge-based view, this might mean borrowing aspects, practices, and capabilities, such as technology, structure, culture, information, expertise, and learning from each of these strategic imperatives to optimise capability and reduce cost.

\subsection{The concept of aligning INNO and KMC}

In practice, innovation and knowledge management work off each other, thus supporting a more prominent desire to align the implementation of INNO and KMC. For instance, innovation is a practice that recombines current knowledge - both implicit and explicit - in a way that generates innovative products or services [29]. Organisational innovation thus shows that the vital role in guiding the design of knowledge management instruments to execute knowledge management activities effectively and, in turn, possibly to provide feedback that further supports organisational innovation [30].

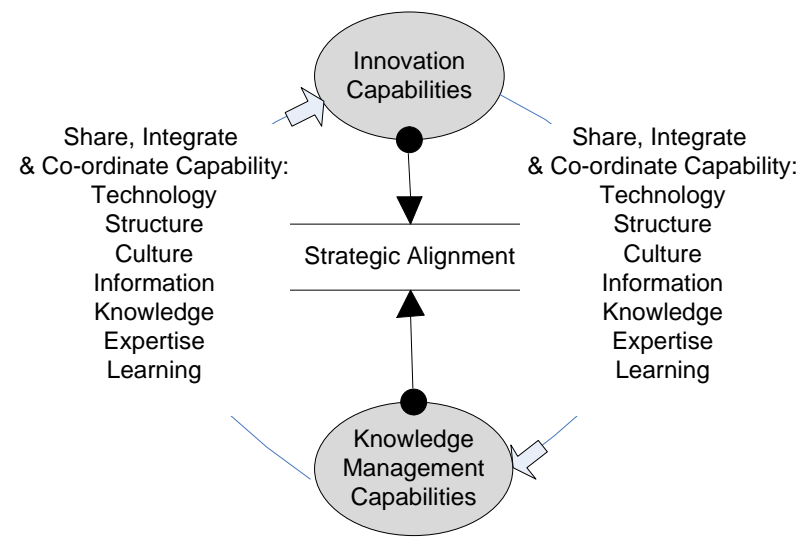

Figure 1: The concept of the alignment of INNO and KMC

The focus of this study was not to replace existing frameworks for knowledge management and innovation, but rather to develop knowledge of the alignment/synthesis of the KMC and INNO constructs, and to determine whether the alignment of these constructs, when done in the order of their importance, improved OCE.

The relevant hypotheses are presented below:

\section{Hypothesis 1}

$\mathrm{H}_{0}{ }^{1} \quad$ INNO does not affect OCE.

$\mathrm{H}_{1}$ : INNO positively affects OCE. 


\section{Hypothesis 2}

$\mathrm{H}_{0}{ }^{2} \quad$ KMC does not affect OCE.

$\mathrm{H}_{2}$ : $\quad$ KMC positively affects OCE.

\section{Hypothesis 3}

$\mathrm{H}_{0}{ }^{3}$ The combination of INNO and KMC does not have a larger positive effect on OCE than their individual effects on OCE.

$\mathrm{H}_{3}$ : The combination of INNO and KMC has a larger positive effect on OCE than their individual effects on OCE.

\subsection{Model of literature review}

This paper proposes a model that extends the models that are currently available in the literature, and argues that there is a relationship between INNO and KMC on the one hand and OCE on the other.

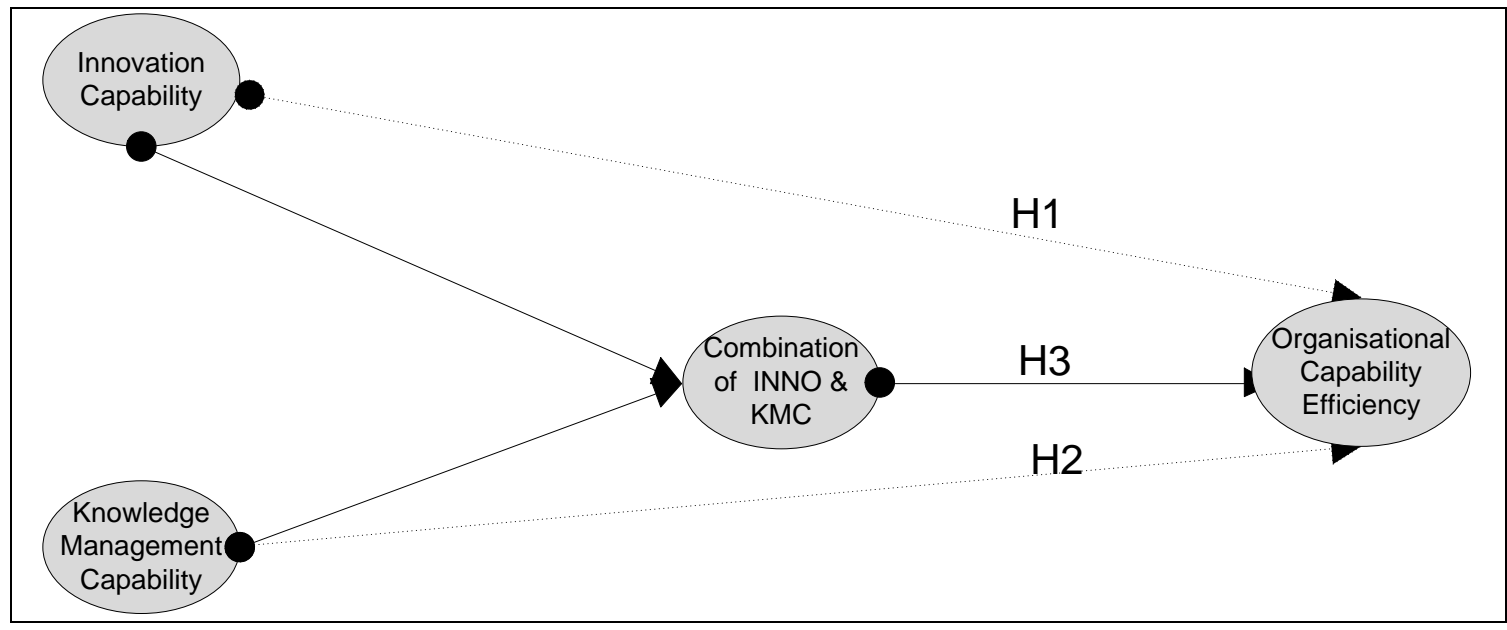

Figure 2: Model of literature review: Aligning INNO and KMC.

Based on the discussion on the alignment of INNO, KMC, and OCE theory that has been described above, and the hypotheses that have been formulated, single model of a literature review can be formulated, as shown in Figure 2.

\section{RESEARCH METHODOLOGY}

The theoretical and empirical knowledge of INNO and KMC, of OCE, and of strategic alignment was reviewed. Each of the capabilities of INNO and KMC was discussed in detail. Resource-based capability and knowledge-based capability theories were discussed, and the existing theoretical models and definitions that were applicable to INNO, KMC, and OCE were reviewed. This study used exploratory research as its survey research design. Exploratory research is defined as research that is used to investigate a problem that is not clearly defined [31]. It was conducted to have a better understanding of the existing problem, because the main purpose of this research was to investigate the relationship between the variables INNO, KMC, and OCE. The study's objective was to determine whether OCE is affected positively by aligning/synthesising organisational capabilities when implementing innovation and knowledge management strategic imperatives for organisations. These objectives led to a positivist, objective approach to the study.

\subsection{Population and sampling procedure}

The target population consisted of all organisations, including national government departments, stateowned enterprises, and listed companies that are engaged in innovation and knowledge management in South Africa. No sampling was done in this study because the researcher conducted a census survey. The researcher did not know how many employees who qualified were in each of the organisations. Two hundred and ninety-one (291) respondents correctly completed the questionnaires used for the analysis. Cresswell [31] recommends that, for factor analysis (a statistical technique used in this study), "the minimum sample size for reliable results is at least 100 observations". 


\subsection{Research data and statistical analysis}

The analyses that were conducted in this study are shown in Table 1 and Table 2.

Table 1: Descriptive analysis

\begin{tabular}{|c|c|}
\hline $\begin{array}{l}\text { DESCRIPTIVE ANALYSIS (i.e., calculating measures } \\
\text { of central tendency and variation in data, and } \\
\text { making frequency distributions) }\end{array}$ & REASON \\
\hline Exploratory analysis (frequency distribution) & $\begin{array}{l}\text { To edit the data by checking for outliers to find out whether } \\
\text { or not it makes sense. }\end{array}$ \\
\hline $\begin{array}{l}\text { Calculations of mean score, standard deviation, } \\
\text { frequencies, and percentages }\end{array}$ & To summarise the data and profile the target population. \\
\hline $\begin{array}{l}\text { Reliability tests (using Cronbach's alpha } \\
\text { coefficient) }\end{array}$ & $\begin{array}{l}\text { To determine whether the variables (i.e., constructs) were } \\
\text { measured consistently and were thus reliable. }\end{array}$ \\
\hline
\end{tabular}

Table 2: Inferential analysis [32]

\begin{tabular}{|l|l|}
\hline INFERENTIAL ANALYSIS & REASON \\
\hline Correlational analysis & $\begin{array}{l}\text { Correlation analysis is used to conclude whether two scale variables } \\
\text { (continuous) variables are linearly related. It determines whether factor } \\
\text { analysis was worthwhile by using the KMO test. }\end{array}$ \\
\hline Normality tests & $\begin{array}{l}\text { Normality tests are used to conclude whether the observed distribution is } \\
\text { normally distributed. This is done using a Chi-squared test, Kolmogorov- } \\
\text { Smirnov, and/or Shapiro-Wilk tests. }\end{array}$ \\
\hline Exploratory factor analysis & To explore and know the underlying factors of a construct. \\
\hline Confirmatory factor analysis & To test theories and for construct validity. \\
\hline SEM & To test the hypotheses and the proposed model. \\
\hline
\end{tabular}

\section{Instrument}

Questionnaires are possibly the most widely used primary data collection method in quantitative surveys [26]. The justification for using questionnaires is that they are mostly easy to analyse, and provide the possibility to transform the data into quantifiable facts and results. In this study, each item in the opinionrelated sections of the questionnaire was measured on an ordinal Likert-type scale with five categories (numbered 1-5). By summating the responses of these items (related to the same issue), the researcher created a more continuous type of variable. Variables like these (continuous) lend themselves to more sophisticated and multivariate statistical analysis techniques [32]. The landscape of the data and the association between the method and the research objectives were carefully considered when selecting the right statistical methods for this study.

\subsection{Method of data analysis}

First, the frequencies and/or descriptive of each item or question were captured. No incorrect data entries were allowed on the system. Users were constrained to select only 1 to 5 in the Likert scales. If nothing was selected for a particular question, the system showed an error. The emailed questionnaires were inspected for correctness. In addition, the captured and stored answers were inspected for correctness. The software program Statistical Packages for the Social Sciences (SPSS), which is designed for statistical processing, was used to analyse the data.

In general, path diagrams are a perfect way to summarise SEMs, where observed variables are shown as boxes and latent variables are shown as circles or ellipses [19]. When one variable is thought to 'cause' another variable, the relationship between the variables is shown as a directed or one-headed arrow, from cause to effect. The coefficients between two variables are also included as SEM, using a curved, twoheaded arrow that relates the variables. For each arrow there can be an estimated loading or weight.

The resulting factors from the CFA were used in the SEM, which was constructed and analysed using analysis of a moment structures (AMOS) graphics [33]. AMOS is statistical software that is an add-on SPSS module, particularly used for SEM, path analysis, and confirmatory factor analysis. It is also identified as causal modelling software. However, the SEM for multivariate analyses with ordinal data was used for data analysis. For this paper, a correlation matrix was used to determine the overall relationship of INNO, KMC, and OCE. This was important to show significant correlations and interrelatedness among INNO, KMC, and OCE.

SEM may comprise one or more linear regression equations that show how some variables depend on others [34]. A linear regression model is a mathematical equation having a dependent variable on the left-hand side but independent variables on the right-hand side. The model is fitted to determine the effects of the 
independent variables on the dependent variable. These are referred to as structural equations, and the collection of them is named the SEM. The coefficients describing how dependent variables depend on independent variables are sometimes called path coefficients.

\section{RESULTS AND DISCUSSION}

The key constructs in this study were INNO, KMC, and OCE.

\subsection{Respondents' profile}

The majority of the respondents - i.e., 71.1 per cent of them - were involved in six or more innovation and/or knowledge management programmes. A large number of respondents (63.3 per cent) had been employed for ten years or more in the area of innovation and/or knowledge management. According to the results, 96.2 per cent had at least a degree or diploma, which indicated that the respondents who completed the questionnaire had at least a tertiary level of education.

\subsection{Factor analysis}

Factor analysis was conducted by investigating the pattern of correlations between the observed measures. The measures that were highly correlated (either positively or negatively) were likely to be affected by the same underlying factors, whereas those that were relatively uncorrelated were likely to be affected by diverse factors.

The variance-explained criterion was applied. The researchers used the rule of keeping enough factors to account for at least 50 per cent of the variation in the data, while the aim was to emphasise parsimony (explaining variance with as few factors as possible). Before excluding questions that make up a factor, but that explain very few additional variables, the researcher checked its correlation with the dependent variable. Every factor consisting of a small number of items can have a large correlation with the dependent variable, in which case it should not be dropped.

For factor analysis, the Kaiser-Meyer-Olkin (KMO) test was adopted to measure sampling adequacy. KMO is an index that is used to associate the magnitudes of the observed correlation coefficients with the magnitudes of the partial correlation coefficients [35]. The KMO value should be greater than 0.5 for a satisfactory factor analysis to continue. Large values for the KMO measure indicate that a factor analysis of the variables is justified. Bartlett's test of sphericity was used to test the null hypothesis that the variables in the population correlation matrix were uncorrelated. In order to proceed with the exploratory factor analysis (EFA), the p-value of this test (i.e., that the items were correlated) had to be rejected, otherwise there was multicollinearity. In addition, confirmatory factor analysis (CFA) was done on every key construct - i.e., INNO, KMC, and OCE - to test its validity. This was done to verify the factor structure of the set of observed variables that constituted the construct.

\subsection{Factors of constructs and reliability tests}

A commonly used method in measuring the reliability of an underlying factor is Cronbach's coefficient (alpha value).

The usage of Cronbach's alpha aimed to prove the reliability or the internal consistency of the items forming a factor, according to the EFA [36]. The values should range between 0 and 1.0, with higher values representing a higher reliability between the items. A low alpha value $(<0.7)$ shows that the underlying factor is not reliable. Should a single item increase the reliability of the factor, it is common practice to omit it from the factor as a way to increase the alpha value of the factor [32].

\subsection{Cronbach's alpha analysis provided the following measures of reliability for INNO}

- INNO 1

(Conceptualising, designing, implementing, and commercialising innovation programmes) consisted of two factors with reliability measures of 0.869 and 0.684 respectively.

\section{- INNO 2}

(The knowledge of competitor strategies, industry trends, and customer needs for innovation) consisted of two factors with reliability measures of 0.905 and 0.799 respectively.

\section{- INNO 3}

(The knowledge of the technology environment and of emerging trends for innovation) consisted of two factors with reliability measures of 0.913 and 0.704 respectively. 


\section{- $\quad$ INNO 4}

(Managing organisational culture, structure, resources, and competencies for innovation) consisted of two factors with reliability measures of 0.867 and 0.835 respectively.

- INNO 5

(Generating ideas in-house or through collaborative efforts, or cross-pollinating ideas, or partner engagement) consisted of two factors, with factor 1 having the reliability measure of 0.924 .

- INNO 6

(Prioritising ideas and converting them into products or processes that create value for innovation) consisted of two factors with reliability measures of 0.854 and 0.833 respectively.

- $\quad$ INNO 7

(Screening and performing selection process, risk management, and strategic disruptive decisionmaking for innovation) consisted of two factors with reliability measures of 0.881 and .800 respectively.

- $\quad$ INNO 8

(Undertaking new product development, customer engagement, and assessing market potential for innovation) consisted of three factors with reliability measures of $0.826,0.771$ and 0.683 respectively.

- $\quad$ INNO 9

(Doing new business development and partner engagement for innovation) consisted of two factors with reliability measures of 0.890 and 0.801 respectively.

- INNO 10

(Delivering value to the customer and capturing a part of that value for innovation) consisted of two factors with reliability measures of 0.876 and 0.831 respectively.

- $\quad$ INNO 11

(Penetrating multiple channels, customer groups, and competitive regions with innovation) consisted of two factors with reliability measures of 0.880 and 0.867 respectively.

KMC had a single factor with a reliability measure of 0.945 . Cronbach's alpha analysis provided the following measure of reliability for knowledge management capability:

OCE: OCE had a single factor with a reliability measure of 0.703 .

Refer to Annexure A for the derivation of the factors.

SEM was applied to analyse the structural relationships. This research method is the combination of factor analysis and multiple regression analysis. It is used to analyse the structural relationships between measured variables and latent constructs. So SEM, apart from being used to develop a framework, was also used to test the three hypotheses.

\subsection{Hypotheses testing}

This study sought to explore the effect of the alignment of INNO and KMC with OCE.

Table 3: Model fit criteria and acceptable fit interpretation [32]

\begin{tabular}{|l|l|l|}
\hline Model fit criterion & Acceptable level & Obtained value \\
\hline Minimum discrepancy divided by & $>1$ and < 3 & 1.373 \\
degrees of freedom (CMIN/DF ( & & \\
\hline $\begin{array}{l}\text { Root mean square error of } \\
\text { approximation (RMSEA) }\end{array}$ & $<0.080$ & 0.036 \\
\hline Normed fit index (NFI) & 0 (no fit) to 1 (perfect fit) & 0.991 \\
\hline Incremental fit index (IFI) & 0 (no fit) to 1 (perfect fit) & \\
\hline P-value for test of close fit (PCLOSE) & 0 (no fit) to 1 (perfect fit) & 0.755 \\
\hline Comparative fit index (CFI) & 0 (no fit) to 1 (perfect fit) & 0.998 \\
\hline $\begin{array}{l}\text { Parsimony comparative fit index } \\
\text { (PCFI) }\end{array}$ & 0 (no fit) to 1 (perfect fit) & 0.154 \\
\hline
\end{tabular}

The various model fit criteria are summarised in Table 3 above. The diagnostic test outcomes of the SEM attained for the proposed conceptual model revealed a good model fit, and all the other measures of model fit were acceptable. For example, $\mathrm{CMIN} / \mathrm{DF}=1.373, \mathrm{NFI}=.991$, $\mathrm{RAMSEA}=0.036<.08$, and $\mathrm{PCFI}=0.154$, which implied that the model fit was acceptable. 


\subsection{Path analysis}

The path analysis assesses and describes the causal effects among the variables tested. Figure 4 below refers to the SEM, showing the measurement and structural components involved with INNO, KMC, and OCE. The SEM provides the inter-relationships of the factors affecting CIK and OCE. The figure has two measured variables (i.e., INNO and KMC) that form the CIK latent variable. The figures mean that the estimated regression weights or coefficients and the figures in brackets were their corresponding standard errors. They had more-or-less equal regression weights of around 1. OCE was measured by a single variable.

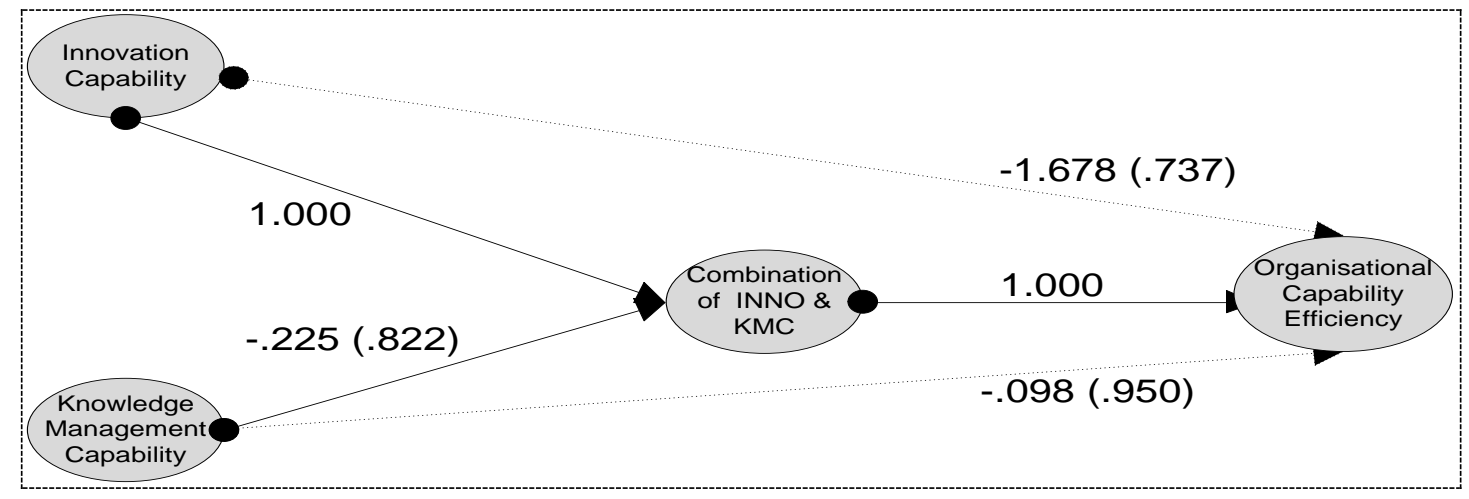

Figure 3: SEM model

These findings imply the following results of the hypotheses testing:

\section{Hypothesis 1}

The purpose of hypothesis 1 was to answer the exploratory question whether INNO affects OCE.

$\mathrm{H}_{0}{ }^{1}$ INNO does not affect OCE.

$H_{1}$ : INNO affects OCE.

The null hypothesis, that INNO $(B=-1.678$, prob.=.737>.05) does not affect OCE, was not rejected. From the results, there was sufficient evidence that there was no significant relationship between INNO and OCE.

\section{Hypothesis 2}

The purpose of hypothesis 2 was to answer the exploratory question whether KMC affects OCE.

$\mathrm{H}_{0}^{2}$ KMC does not affect OCE.

$\mathrm{H}_{2}$ : KMC affects OCE.

The null hypothesis, that $K M C$ ( $B=-.098$, prob. $=0.950>.05)$ does not affect OCE, was not rejected. From the results, there was sufficient evidence that there was no significant relationship between KMC and OCE.

\section{Hypothesis 3}

The purpose of hypothesis 3 was to answer the exploratory question whether combining INNO and KMC affect OCE more significantly than these strategies considered individually.

$\mathrm{H}_{0}{ }^{3}$ The combination of INNO and KMC does not have a larger positive effect on OCE than their effects on OCE individually.

$\mathrm{H}_{3}$ : The combination of INNO and KMC has a larger positive effect on OCE than their effects on OCE individually.

The null hypothesis was rejected, and the alternative - that the combination of INNO and KMC $(B=1.000)$ has a larger positive effect on OCE than their effects on OCE individually - was accepted. From the results, there was sufficient evidence that the effect of combining INNO with KMC was higher than the sum of the effects of the individual components in this model.

This confirmed that an organisation that implements INNOs should seriously consider aligning/ synthesising the appropriate KMCs to improve OCE. 
From the SEM analysis, it was found that INNO and KMC do not affect OCE individually. However, from the results of the study there was sufficient evidence that the effect of combining INNO with KMC is higher than the sum of the effects of the individual components of this model. Therefore organisations that are implementing INNO and KMC on their own will not experience OCE. However, the results showed that implementing INNO combined with KMC will benefit the OCE.

CIK was used as the latent variable, and both CIK and OCE had regression weights of around 1.000.

\section{MANAGERIAL IMPLICATIONS}

\subsection{Theoretical implications}

SEM can theoretically be used to answer all research questions involving the indirect or direct observation of one or more independent variables or one or more dependent variables. However, the main aim of SEM is to determine and validate a proposed causal process and/or model. Therefore, for academics this improves the connection and understanding of INNO and KCE and the link to OCE. This contributes to the existing literature.

\subsection{Practical implications}

Innovation capability and knowledge management capability being coherently aligned will allow managers and practitioners to have cohesive strategies, to optimise their utilisation of resources, to avoid redundancy of effort, to improve their investments, and to improve their access to highly scarce and skilled resources. The study has provided a greater understanding of the relationship between innovation capability, knowledge management capability, and organisational capability efficiency, and will inform business managers, knowledge managers, innovators, and project managers about the appropriate investment in an aligned/synthesised implementation of innovation capability and knowledge management capability for their organisation.

\section{RECOMMENDATIONS}

The following are recommendations arising from the study:

a) The research suggests that organisations implementing INNO and KMC on their own face the risk of inefficiency of organisational capability. It is recommended that, when implementing INNO in an organisation, KMC concepts should be considered and, where applicable, it should align or synthesise them with the appropriate INNO, using their order of importance to prioritise the implementation.

b) It is strongly suggested that organisations implementing INNO and KMC consider aligning their capabilities to attain OCE and to overcome the struggle with multiple influences and depleted organisational capability. The most important things that are needed for innovation capability and knowledge management capability to happen are: the top management or leadership, organisational cultural change; training staff to acquire the necessary skills; and transformation and change management.

\section{SUGGESTIONS FOR FURTHER RESEARCH}

The results obtained in this study are likely to provide researchers with a better understanding of innovation capability, knowledge management capability, and organisational capability efficiency, and to provide a basis for further research into this important aspect of today's knowledge and intellectual organisations.

The following are suggestions for further research:

a) The insight into the INNO, KMC, and OCE conceptual framework can be used as a basis to explore other areas of interest in the wide area of innovation and knowledge management.

b) From the results, there is empirical evidence that INNO influences OCE negatively and that KMC influences OCE negatively. INNO and KMC affect OCE more significantly than when these strategies are considered individually. Further studies should be undertaken to examine why INNO and KMC, when implemented on their own, negatively affect OCE.

c) The homogeneous nature of INNO and KMC was interestingly brought out in this study, especially their shared benefits. Further research could be done to see how other homogeneous strategic imperatives, such as centre of excellence, align. Questions to consider include: How does the alignment of centre 
of excellence capability and innovation capability and/or the alignment of centre of excellence capability with knowledge management capability affect organisations?

Although the sample size was acceptable, potential bias existed, which was a possible limitation of the study. The use of a questionnaire was a possible limitation, as it did not allow for observation and rapport with the respondents. In addition, the data were collected from South African organisations. However, the characteristics of the surveyed organisations might be quite different from organisations in other countries. Thus its generalisability is limited to other similar contexts.

\section{CONCLUSION}

The study confirmed that INNO and KMC do not affect individually affect OCE. Organisations that are implementing INNO and KMC on their own will not experience OCE. However, the results showed that implementing INNO combined with KMC would benefit the OCE.

The study has closed the gaps in respect of the lack of models, and has made advances in the study of the relationship between KMC, INNO, and OCE and the importance of their underlying constructs. The researcher has not come across any theory that shows the interrelationships of innovation capability, knowledge management capability, and organisational capability efficiency. Therefore the structured equation model that was derived is considered to be an original contribution to the body of knowledge.

INNO and KMC being coherently aligned would allow managers and practitioners to have cohesive strategies, to optimise their utilisation of resources, to avoid redundancy of effort, to improve their investments, and to improve their access to highly scarce and skilled resources. The study has provided a greater understanding of the relationship between INNO, KMC, and OCE, and will inform business managers, knowledge managers, innovators, and project managers on the appropriate investment in an aligned/synthesised implementation of INNO and KMC in their organisation.

\section{REFERENCES}

[1] Godin, B. 2012. Innovation studies: The invention of a specialty. Minerva, 50(4), pp. 397-421.

[2] Damanpour, F. 1991. Organizational innovation: A meta-analysis of effects of determinants and moderators. Academy Management Journal, 34(3), pp. 555-590.

[3] Gopalakrishnan, S. \& Damanpour, F. 1997. A review of innovation research in economics, sociology and technology management. Omega, 25(1), pp. 15-28.

[4] Dobni, C.B. \& Sand, C. 2018. Strategy shift: Integrating strategy and the firm's capability to innovate. Business Horizons, 61(1), pp. 797-808.

[5] Chen, C.J. \& Huang, J.W. 2009. Strategic human resource practices and innovation performances: The mediating role of knowledge management capacity. Journal of Business Research, 62(1), pp. 104-114.

[6] Huang, J.W. \& Li, Y.H. 2009. The mediating effect of knowledge management on social interaction and innovation performance. International Journal of Manpower, 30(3), pp. 285-301.

[7] Wilson, G. 2007. Knowledge, innovation and re-inventing technical assistance for development. Progress in Development Studies, 7(3), pp. 183-199.

[8] Souza, J.C. \& Bruno-Faria, M. 2013. The innovation process in the organisational context: An analysis of helping and hindering factors. Brazilian Business Review, 10(3), pp. 108-129.

[9] Podrug, N., Filipović, D. \& Kovač, M. 2017. Knowledge sharing and firm innovation capability in Croatian ICT companies. International Journal of Manpower, 38(4), pp. 632-644.

[10] Aujirapongpan, S., Vadhanasindhu, P., Chandrachai, A. \& Cooparat, P. 2010. Indicators of knowledge management capability for knowledge management effectiveness. The Journal of Information and Knowledge Management Systems, 40(2), pp. 183-203.

[11] Beijerse, R.P.U. 1999. Questions in knowledge management: Defining and conceptualizing a phenomenon. Journal of Knowledge Management, 3(2), pp. 94-109.

[12] Andreeva, T. \& Kianto, A. 2011. Knowledge processes, knowledge intensity and innovation: A moderated mediated analysis. Journal of Knowledge Management, 15(6), pp. 1016-1034.

[13] Kör, B. \& Maden, C. 2013. The relationship between knowledge management and innovation in Turkish service and high-tech firms. International Journal of Business and Social Science, 4(4), pp. 293-304.

[14] Durmus-Özdemir, E. \& Abdukhoshimov, K. 2018. Exploring the mediating role of innovation in the effect of the knowledge management process on performance. Technology Analysis and Strategic Management, 30(5), pp. 596680.

[15] Kumar, K.G.S., Thampi, P.P., Jyotishi, A. \& Bishu, R. 2013. Towards strategically aligned innovative capability: A QFD-based approach. Quality Management Journal, 20(4), pp. 37-50. 
[16] Slavkovic, M. \& Babic, V. 2013. Knowledge management, innovativeness, and organisational performance: Evidence from Serbia. Economic Annals, 199(1), pp. 85-107.

[17] Wuryaningrat, N.F.D. 2013. Knowledge sharing, absorptive capacity and innovation capabilities: An empirical study on small and medium enterprises in North Sulawesi, Indonesia. International Journal of Business, 15(1) pp. 61-78.

[18] Lin, H., McDonough III, E., Lin, S. \& Lin, C. 2013. Managing the exploitation / exploration paradox: The role of a learning capability and innovation ambidexterity. Product Development and Management Association, 30(2), pp. 262-278.

[19] Martinez-Conesa, I., Soto-Acosta, P. \& Carayannis, E.G. 2017. On the path towards open innovation: Assessing the role of knowledge management capability and environmental dynamism in SMEs. Journal of Knowledge Management, 21(3), pp. 553-570.

[20] Al-Hakim, L.A. \& Hassan, S. 2016. Core requirements of knowledge management implementation, innovation and organisational performance. Journal of Business Economics and Management, 17(1), pp. 109-124.

[21] Elbeltagi, I. \& Al-Husseini, S. 2015. Knowledge sharing practices as a basis of product innovation: A case of higher education in Iraq. VL - 5 International Journal of Social Science and Humanity, 5(2), pp. 101-124.

[22] Shujahat, M., Sousa, M.J., Hussain, S., Nawaz, F., Wang, M. \& Umer, M. 2017. Translating the impact of knowledge management processes into knowledge-based innovation: The neglected and mediating role of knowledge-worker productivity. Journal of Business Research, 94(1), pp. 442-450.

[23] Kör, B. \& Maden, C. 2013. The relationship between knowledge management and innovation in Turkish service and high-tech firms. International Journal of Business and Social Science, 4(4), pp. 293-304.

[24] Teece, D.J. 2000. Strategies for managing knowledge assets: The role of firm structure and industrial context. Long Range Planning, 33(1), pp. 35-54.

[25] McKinsey. (2015). Building organisational capabilities: McKinsey global survey results. [Online]. Available from: https://www.mckinsey.com/business-functions/organization/our-insights/building-organizational-capabilitiesmckinsey-global-survey-results\#. Accessed 3 September 2020.

[26] Cooper, C.R. \& Schindler, P.S. 2011. Business research methods. $11^{\text {th }}$ ed. New York: McGraw-Hill.

[27] Heisig, P. 2014. Knowledge management: Advancements and future research needs. Global Knowledge Research Network. Leeds: Leeds University Business School.https://link.springer.com/chapter/10.1007\%2F978-3-31909501-1_7

[28] Shafique, M. 2013. Thinking inside the box? Intellectual structure of the knowledge base of innovation research (1988-2008). Strategic Management Journal, 34(1), pp. 62-93.

[29] Del Giudice, M. \& Della Peruta, M.R. 2016. The impact of IT based knowledge management systems or internal venturing and innovation: A SEM modeling approach to corporate performance. Journal of Knowledge Management, 20(3), pp. 484-498.

[30] Laforet, S. 2013. Organisational innovation outcomes in SMEs: Effects of age, size, and sector. Journal of World Business, 48(4), pp. 490-502.

[31] Creswell, J.W. 2012. Educational research: Planning, conducting, and evaluating quantitative and qualitative research. $4^{\text {th }}$ ed. Boston: Pearson Education.

[32] Hair, J.F., Tatham, R.L., Anderson, R.E. \& Black, W.C. 1995. Multivariate data analysis. $4^{\text {th }}$ ed. New York, NY: Prentice Hall.

[33] Byrne, B.M. 2010. SEM modeling with AMOS: Basic concepts, applications, and programming. 2nd ed. New York, NY: Routledge.

[34] Kline, R.B. 1998. Principles and practice of structural equation modeling. New York, NY: Guilford Press.

[35] George, D. \& Mallery, M. 2010. SPSS for Windows step by step: A simple guide and reference. $10^{\text {th }}$ ed. Boston, MA: Pearson.

[36] Field, A. 2005. Discovering statistics using SPSS. $2^{\text {nd }}$ ed. London: Sage. 


\begin{tabular}{|c|c|c|c|c|c|c|c|}
\hline Serial no. & Construct & $\begin{array}{l}\text { Samp } \\
\text { le } \\
\text { size }\end{array}$ & Mean score & Std dev. & t-value & P-value & Decisi \\
\hline B1 & \multicolumn{7}{|c|}{ Strategic: Conceptualising idea } \\
\hline B1[1] & Technology & 291 & 1.79 & .844 & -24.505 & .000 & reject \\
\hline B1[2] & Structure: $\mathrm{COE}$ & 291 & 1.61 & .942 & -25.152 & .000 & reject \\
\hline $\mathrm{B} 1[3]$ & Structure: & 291 & 1.93 & .867 & -20.971 & .000 & reject \\
\hline B1[4] & Structure: Informal & 291 & 1.70 & 1.028 & -21.494 & .000 & reject \\
\hline B1[5] & Culture & 291 & 1.80 & .886 & -23.016 & .000 & reject \\
\hline $\begin{array}{l}\text { B } \\
B 1[6]\end{array}$ & $\begin{array}{ll}\text { K\&l: } & \begin{array}{l}\text { Strategic } \\
\text { resource }\end{array}\end{array}$ & 291 & 1.82 & .824 & -24.414 & .000 & reject \\
\hline B1[7] & $\begin{array}{ll}\text { K\&l: } & \text { Valuable } \\
\text { informati } \\
\text { on }\end{array}$ & 291 & 1.54 & .848 & -29.397 & .000 & reject \\
\hline B1[8] & K\&l: Interpretation & 291 & 1.80 & .949 & -21.626 & .000 & reject \\
\hline B1[9] & K\&l: Transferability & 291 & 1.95 & .859 & -20.778 & .000 & reject \\
\hline B1[10] & $\begin{array}{l}\text { Expertise: } \\
\text { Intellectu } \\
\text { al asset }\end{array}$ & 291 & 1.55 & .939 & -26.271 & .000 & reject \\
\hline $\mathrm{B} 1[11]$ & $\begin{array}{c}\text { Expertise: Pointers } \\
\text { to expert }\end{array}$ & 291 & 1.48 & .844 & -30.695 & .000 & reject \\
\hline $\mathrm{B} 1[12]$ & Learning & 291 & 1.51 & \begin{tabular}{|l|l|}
.892 \\
\end{tabular} & -28.523 & .000 & reject \\
\hline B2 & \multicolumn{7}{|c|}{ Strategic: Knowledge of competitors \& industry trends } \\
\hline B2[1] & Technology & 291 & 1.96 & .868 & -20.534 & .000 & reject \\
\hline B2[2] & Structure: $\mathrm{COE}$ & 291 & 2.42 & .984 & -10.005 & .000 & reject \\
\hline B2[3] & $\begin{array}{l}\text { Structure: } \\
\text { Command }\end{array}$ & 291 & 2.10 & .920 & -16.763 & .000 & reject \\
\hline B2[4] & Structure: Informal & 291 & 1.80 & 1.059 & -19.380 & .000 & reject \\
\hline $\begin{array}{ll}\mathrm{B} L \mathrm{~L} \\
\mathrm{~B} 2[5]\end{array}$ & Culture & 291 & 1.59 & .954 & -25.122 & .000 & reject \\
\hline B2[6] & $\begin{array}{ll}\text { K\&l: } & \begin{array}{c}\text { Strategic } \\
\text { resource }\end{array}\end{array}$ & 291 & 1.56 & .878 & -27.966 & .000 & reject \\
\hline B2[7] & $\begin{array}{ll}\text { K\&l: } & \begin{array}{l}\text { Valuable } \\
\text { informati } \\
\text { on }\end{array}\end{array}$ & 291 & 2.33 & 1.022 & -11.132 & .000 & reject \\
\hline B2[8] & K\&l: Interpretation & 291 & 2.03 & .824 & -20.071 & .000 & reject \\
\hline B2[9] & K\&l: Transferability & 291 & 2.75 & 1.271 & -3.366 & .001 & reject \\
\hline $\mathrm{B} 2[10]$ & $\begin{array}{l}\text { Expertise: } \\
\text { Intellectu } \\
\text { al asset }\end{array}$ & 291 & 2.62 & 1.309 & -5.016 & .000 & reject \\
\hline B2[11] & $\begin{array}{c}\text { Expertise: Pointers } \\
\text { to expert }\end{array}$ & 291 & 2.65 & 1.295 & -4.662 & .000 & reject \\
\hline B2[12] & Learning & 291 & 1.92 & .908 & -20.268 & .000 & reject \\
\hline B3 & \multicolumn{7}{|c|}{ Strategic: Technology \& emerging trends } \\
\hline B3[1] & Technology & 291 & 1.50 & .970 & -26.415 & .000 & reject \\
\hline $\mathrm{B} 3[2]$ & Structure: $\mathrm{COE}$ & 291 & 1.73 & 1.019 & -21.229 & .000 & reject \\
\hline$B 3[3]$ & $\begin{array}{l}\text { Structure: } \\
\text { Command }\end{array}$ & 291 & 2.72 & 1.325 & -3.629 & .000 & reject \\
\hline B3[4] & Structure: Informal & 291 & 1.79 & 1.114 & -18.477 & .000 & reject \\
\hline 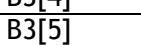 & Culture & 291 & 1.60 & 1.006 & -23.656 & .000 & reject \\
\hline B3[6] & $\begin{array}{ll}\text { K\&l: } & \begin{array}{c}\text { Strategic } \\
\text { resource }\end{array}\end{array}$ & 291 & 1.54 & .965 & -25.806 & .000 & reject \\
\hline B3[7] & $\begin{array}{ll}\text { K\&l: } & \text { Valuable } \\
\text { informati } \\
\text { on }\end{array}$ & 291 & 1.60 & .925 & -25.866 & .000 & reject \\
\hline B3[8] & K\&l: Interpretation & 291 & 2.38 & 1.008 & -10.406 & .000 & reject \\
\hline B3[9] & K\&l: Transferability & 291 & 2.02 & .904 & -18.549 & .000 & reject \\
\hline B3[10] & $\begin{array}{l}\text { Expertise: } \\
\text { Intellectu } \\
\text { al asset }\end{array}$ & 291 & 1.65 & .991 & -23.317 & .000 & reject \\
\hline $\mathrm{B} 3[11]$ & $\begin{array}{c}\text { Expertise: Pointers } \\
\text { to expert }\end{array}$ & 291 & 1.60 & .939 & -25.353 & .000 & reject \\
\hline B3[12] & Learning & 291 & 1.60 & .999 & -23.818 & .000 & reject \\
\hline before & \multicolumn{7}{|c|}{ Strategic: Culture \& structure } \\
\hline
\end{tabular}




\begin{tabular}{|c|c|c|c|c|c|c|c|}
\hline B4[1] & Technology & 291 & 2.31 & 1.095 & -10.813 & .000 & reject \\
\hline$B 4[2]$ & Structure: COE & 291 & 1.69 & 1.068 & -20.975 & .000 & reject \\
\hline B4[3] & $\begin{array}{l}\text { Structure: } \\
\qquad \text { Command }\end{array}$ & 291 & 1.95 & .964 & -18.553 & .000 & reject \\
\hline B4[4] & Structure: Informal & 291 & 2.37 & 1.114 & -9.686 & .000 & reject \\
\hline B4[5] & Culture & 291 & 2.19 & 1.083 & -12.831 & .000 & reject \\
\hline B4[6] & $\begin{array}{ll}\text { K\&l: } & \begin{array}{c}\text { Strategic } \\
\text { resource }\end{array}\end{array}$ & 291 & 1.82 & .859 & -23.335 & .000 & reject \\
\hline B4[7] & $\begin{array}{ll}\text { K\&l: } & \text { Valuable } \\
& \text { informati } \\
\text { on }\end{array}$ & 291 & 2.36 & 1.019 & -10.638 & .000 & reject \\
\hline B4[8] & K\&l: Interpretation & 291 & 2.35 & .994 & -11.152 & .000 & reject \\
\hline B4[9] & K\&l: Transferability & 291 & 1.67 & .925 & -24.516 & .000 & reject \\
\hline$B 4[10]$ & $\begin{array}{l}\text { Expertise: } \\
\text { Intellectu } \\
\text { al asset }\end{array}$ & 291 & 1.61 & .924 & -25.708 & .000 & reject \\
\hline$B 4[11]$ & $\begin{array}{c}\text { Expertise: Pointers } \\
\text { to expert }\end{array}$ & 291 & 1.59 & .883 & -27.150 & .000 & reject \\
\hline$B 4[12]$ & Learning & 291 & 2.26 & 1.076 & -11.769 & .000 & reject \\
\hline $\mathrm{C}$ & Ideation & & & & & & \\
\hline $\mathrm{C} 1[1]$ & Technology & 291 & 1.55 & .965 & -25.693 & .000 & reject \\
\hline $\mathrm{C} 1[2]$ & Structure: $\mathrm{COE}$ & 291 & 1.67 & .983 & -23.029 & .000 & reject \\
\hline C1[3] & $\begin{array}{l}\text { Structure: } \\
\text { Command }\end{array}$ & 291 & 2.40 & 1.054 & -9.681 & .000 & reject \\
\hline C1[4] & Structure: Informal & 291 & 1.68 & .964 & -23.361 & .000 & reject \\
\hline C1[5] & Culture & 291 & 1.53 & .990 & -25.275 & .000 & reject \\
\hline C1[6] & $\begin{array}{cc}\text { K\&l: } & \begin{array}{c}\text { Strategic } \\
\text { resource }\end{array}\end{array}$ & 291 & 1.77 & .853 & -24.533 & .000 & reject \\
\hline C1[7] & $\begin{array}{ll}\text { K\&l: } & \text { Valuable } \\
& \text { informati } \\
\text { on }\end{array}$ & 291 & 1.57 & .878 & -27.790 & .000 & reject \\
\hline C1[8] & K\&I: Interpretation & 291 & 1.70 & .927 & -23.958 & .000 & reject \\
\hline C1[9] & K\&l: Transferability & 291 & 1.70 & .992 & -22.396 & .000 & reject \\
\hline C1[10] & $\begin{array}{l}\text { Expertise: } \\
\qquad \begin{array}{l}\text { Intellectu } \\
\text { al asset }\end{array}\end{array}$ & 291 & 1.64 & .912 & -25.459 & .000 & reject \\
\hline C1[11] & $\begin{array}{c}\text { Expertise: Pointers } \\
\text { to expert }\end{array}$ & 291 & 1.67 & .958 & -23.673 & .000 & reject \\
\hline C1[12] & Learning & 291 & 1.64 & .981 & -23.662 & .000 & reject \\
\hline D1 & $\begin{array}{c}\text { Implementation: } \\
\text { Prioritisin } \\
\text { g ideas }\end{array}$ & & & & & & \\
\hline D1[1] & Technology & 291 & 1.55 & .929 & -26.642 & .000 & reject \\
\hline D1[2] & Structure: COE & 291 & 2.25 & 1.052 & -12.088 & .000 & reject \\
\hline D1[3] & $\begin{array}{l}\text { Structure: } \\
\text { Command }\end{array}$ & 291 & 1.94 & .883 & -20.452 & .000 & reject \\
\hline D1[4] & Structure: Informal & 291 & 2.06 & .871 & -18.441 & .000 & reject \\
\hline D1[5] & Culture & 291 & 1.85 & .825 & -23.806 & .000 & reject \\
\hline D1[6] & $\begin{array}{l}\text { K\&l: } \begin{array}{c}\text { Strategic } \\
\text { resource }\end{array}\end{array}$ & 291 & 2.23 & 1.029 & -12.819 & .000 & reject \\
\hline D1[7] & $\begin{array}{ll}\text { K\&l: } & \begin{array}{l}\text { Valuable } \\
\text { informati } \\
\text { on }\end{array} \\
\end{array}$ & 291 & 2.20 & 1.049 & -12.966 & .000 & reject \\
\hline D1[8] & K\&l: Interpretation & 291 & 2.38 & .976 & -10.868 & .000 & reject \\
\hline D1[9] & K\&l: Transferability & 291 & 2.25 & .958 & -13.400 & .000 & reject \\
\hline D1[10] & $\begin{array}{l}\text { Expertise: } \\
\text { Intellectu } \\
\text { al asset }\end{array}$ & 291 & 1.93 & .846 & -21.470 & .000 & reject \\
\hline D1[11] & $\begin{array}{c}\text { Expertise: Pointers } \\
\text { to expert }\end{array}$ & 291 & 1.60 & .894 & -26.743 & .000 & reject \\
\hline D1[12] & Learning & 291 & 1.62 & .941 & -25.050 & .000 & reject \\
\hline D2 & Implementation: Sele & ction & cess & & & & \\
\hline D2[1] & Technology & 291 & 1.93 & .905 & -20.211 & .000 & reject \\
\hline D2[2] & Structure: COE & 291 & 2.33 & .973 & -11.753 & .000 & reject \\
\hline D2[3] & $\begin{array}{l}\text { Structure: } \\
\qquad \text { Command }\end{array}$ & 291 & 1.63 & .968 & -24.155 & .000 & reject \\
\hline
\end{tabular}




\begin{tabular}{|c|c|c|c|c|c|c|c|}
\hline D2[4] & Structure: Informal & 291 & 2.45 & 1.027 & -9.189 & .000 & reject \\
\hline D2[5] & Culture & 291 & 2.26 & 1.022 & -12.280 & .000 & reject \\
\hline D2[6] & $\begin{array}{cc}\text { K\&l: } & \begin{array}{c}\text { Strategic } \\
\text { resource }\end{array}\end{array}$ & 291 & 2.22 & 1.077 & -12.299 & .000 & reject \\
\hline D2[7] & $\begin{array}{ll}\text { K\&l: } & \text { Valuable } \\
& \text { informati } \\
\text { on }\end{array}$ & 291 & 1.96 & .911 & -19.437 & .000 & reject \\
\hline D2[8] & K\&II: Interpretation & 291 & 2.37 & 1.000 & -10.729 & .000 & reject \\
\hline D2[9] & K\&I: Transferability & 291 & 1.98 & .861 & -20.296 & .000 & reject \\
\hline $\mathrm{D} 2[10]$ & $\begin{array}{c}\text { Expertise: } \\
\text { Intellectu } \\
\text { al asset }\end{array}$ & 291 & 2.24 & .982 & -13.132 & .000 & reject \\
\hline D2[11] & $\begin{array}{c}\text { Expertise: Pointers } \\
\text { to expert }\end{array}$ & 291 & 2.23 & 1.032 & -12.777 & .000 & reject \\
\hline D2[12] & Learning & 291 & 1.59 & .966 & -24.893 & .000 & reject \\
\hline D3 & Implementation: Pro & duct d & lopme & & & & \\
\hline D3[1] & Technology & 291 & 1.59 & 1.011 & -23.827 & .000 & reject \\
\hline D3[2] & Structure: $\mathrm{COE}$ & 291 & 2.35 & 1.007 & -11.063 & .000 & reject \\
\hline D3[3] & $\begin{array}{l}\text { Structure: } \\
\text { Command }\end{array}$ & 291 & 2.33 & 1.018 & -11.233 & .000 & reject \\
\hline D3[4] & Structure: Informal & 291 & 1.76 & 1.050 & -20.212 & .000 & reject \\
\hline D3[5] & Culture & 291 & 1.64 & .966 & -23.961 & .000 & reject \\
\hline D3[6] & $\begin{array}{ll}\text { K\&l: } & \begin{array}{c}\text { Strategic } \\
\text { resource }\end{array} \\
\end{array}$ & 291 & 1.62 & .899 & -26.146 & .000 & reject \\
\hline D3[7] & $\begin{array}{ll}\text { K\&l: } & \text { Valuable } \\
\text { informati } \\
\text { on }\end{array}$ & 291 & 1.56 & .913 & -26.905 & .000 & reject \\
\hline D3[8] & K\&II: Interpretation & 291 & 1.96 & .852 & -20.921 & .000 & reject \\
\hline D3[9] & K\&l: Transferability & 291 & 1.93 & .813 & -22.348 & .000 & reject \\
\hline D3[10] & $\begin{array}{c}\text { Expertise: } \\
\text { Intellectu } \\
\text { al asset }\end{array}$ & 291 & 2.27 & 1.007 & -12.284 & .000 & reject \\
\hline D3[11] & $\begin{array}{c}\text { Expertise: Pointers } \\
\text { to expert }\end{array}$ & 291 & 1.58 & .904 & -26.789 & .000 & reject \\
\hline D3[12] & Learning & 291 & 1.59 & .944 & -25.518 & .000 & reject \\
\hline D4 & Implementation: Bus & iness c & elopme & & & & \\
\hline D4[1] & Technology & 291 & 2.26 & 1.033 & -12.253 & .000 & reject \\
\hline D4[2] & Structure: $\mathrm{COE}$ & 291 & 2.34 & .975 & -11.485 & .000 & reject \\
\hline D4[3] & $\begin{array}{l}\text { Structure: } \\
\text { Command }\end{array}$ & 291 & 1.70 & 1.016 & -21.866 & .000 & reject \\
\hline D4[4] & Structure: Informal & 291 & 2.43 & 1.023 & -9.456 & .000 & reject \\
\hline D4[5] & Culture & 291 & 2.26 & 1.000 & -12.600 & .000 & reject \\
\hline D4[6] & $\begin{array}{ll}\text { K\&l: } & \begin{array}{c}\text { Strategic } \\
\text { resource }\end{array}\end{array}$ & 291 & 1.61 & .942 & -25.152 & .000 & reject \\
\hline D4[7] & $\begin{array}{ll}\text { K\&l: } & \text { Valuable } \\
\text { informati } \\
\text { on }\end{array}$ & 291 & 2.21 & 1.005 & -13.360 & .000 & reject \\
\hline D4[8] & K\&l: Interpretation & 291 & 2.37 & .978 & -11.023 & .000 & reject \\
\hline D4[9] & K\&l: Transferability & 291 & 2.27 & .983 & -12.588 & .000 & reject \\
\hline D4[10] & $\begin{array}{l}\text { Expertise: } \\
\begin{aligned} \text { Intellectu } \\
\text { al asset }\end{aligned}\end{array}$ & 291 & 2.33 & .970 & -11.728 & .000 & reject \\
\hline D4[11] & $\begin{array}{c}\text { Expertise: Pointers } \\
\text { to expert }\end{array}$ & 291 & 1.89 & .793 & -23.870 & .000 & reject \\
\hline D4[12] & Learning & 291 & 1.93 & .921 & -19.741 & .000 & reject \\
\hline E1 & Commercialisation: & ustom & value & & & & \\
\hline E1[1] & Technology & 291 & 1.98 & .919 & -18.882 & .000 & reject \\
\hline E1[2] & Structure: COE & 291 & 1.77 & 1.026 & -20.406 & .000 & reject \\
\hline E1[3] & $\begin{array}{l}\text { Structure: } \\
\text { Command }\end{array}$ & 287 & 1.75 & 1.020 & -20.722 & .000 & reject \\
\hline E1[4] & Structure: Informal & 291 & 2.40 & 1.010 & -10.220 & .000 & reject \\
\hline E1[5] & Culture & 291 & 2.35 & .991 & -11.126 & .000 & reject \\
\hline E1[6] & $\begin{array}{ll}\text { K\&l: } & \begin{array}{c}\text { Strategic } \\
\text { resource }\end{array}\end{array}$ & 291 & 1.61 & .931 & -25.450 & .000 & reject \\
\hline
\end{tabular}




\begin{tabular}{|c|c|c|c|c|c|c|c|}
\hline E1[7] & $\begin{array}{ll}\text { K\&l: } & \text { Valuable } \\
& \text { informati } \\
\text { on }\end{array}$ & 291 & 1.73 & 1.010 & -21.485 & .000 & reject \\
\hline E1[8] & K\&l: Interpretation & 291 & 1.80 & 1.027 & -19.865 & .000 & reject \\
\hline E1[9] & K\&l: Transferability & 291 & 2.30 & .973 & -12.350 & .000 & reject \\
\hline E1[10] & $\begin{array}{l}\text { Expertise: } \\
\begin{aligned} \text { Intellectu } \\
\text { al asset }\end{aligned}\end{array}$ & 291 & 2.31 & .975 & -12.143 & .000 & reject \\
\hline E1[11] & $\begin{array}{c}\text { Expertise: Pointers } \\
\text { to expert }\end{array}$ & 291 & 1.92 & .833 & -22.100 & .000 & reject \\
\hline E1[12] & Learning & 291 & 1.66 & .981 & -23.295 & .000 & reject \\
\hline E2 & \multicolumn{7}{|c|}{ Commercialisation: Channels } \\
\hline E2[1] & Technology & 291 & 1.64 & 1.029 & -22.511 & .000 & reject \\
\hline E2[2] & Structure: $\mathrm{COE}$ & 291 & 1.73 & 1.007 & -21.600 & .000 & reject \\
\hline E2[3] & $\begin{array}{l}\text { Structure: } \\
\text { Command }\end{array}$ & 291 & 1.73 & 1.012 & -21.371 & .000 & reject \\
\hline E2[4] & Structure: Informal & 291 & 1.81 & 1.028 & -19.726 & .000 & reject \\
\hline E2[5] & Culture & 291 & 1.65 & .941 & -24.557 & .000 & reject \\
\hline E2[6] & $\begin{array}{ll}\text { K\&l: } & \begin{array}{c}\text { Strategic } \\
\text { resource }\end{array}\end{array}$ & 291 & 2.30 & .991 & -12.063 & .000 & reject \\
\hline E2[7] & $\begin{array}{ll}\text { K\&l: } & \text { Valuable } \\
& \text { informati } \\
\text { on }\end{array}$ & 291 & 1.56 & .943 & -26.056 & .000 & reject \\
\hline E2[8] & K\&l: Interpretation & 291 & 2.34 & .974 & -11.618 & .000 & reject \\
\hline E2[9] & K\&l: Transferability & 291 & 1.97 & .817 & -21.593 & .000 & reject \\
\hline E2[10] & $\begin{array}{l}\text { Expertise: } \\
\text { Intellectu } \\
\text { al asset }\end{array}$ & 291 & 2.31 & .976 & -12.074 & .000 & reject \\
\hline E2[11] & $\begin{array}{c}\text { Expertise: Pointers } \\
\text { to expert }\end{array}$ & 291 & 2.25 & .997 & -12.878 & .000 & reject \\
\hline$E 2[12]$ & Learning & 291 & 2.33 & 1.000 & -11.490 & .000 & reject \\
\hline $\mathrm{F}$ & \multicolumn{7}{|c|}{ Organisation capability efficiency } \\
\hline F1 & $\begin{array}{l}\text { Optimising } \\
\text { resources }\end{array}$ & 291 & 2.35 & 1.077 & -10.230 & .000 & reject \\
\hline F2 & Mobilising resources & 291 & 1.52 & .844 & -29.998 & .000 & reject \\
\hline F3 & Resource analysis & 291 & 1.81 & .819 & -24.760 & .000 & reject \\
\hline F4 & $\begin{array}{l}\text { Converging } \\
\text { resource } \\
\text { capability }\end{array}$ & 291 & 1.48 & .856 & -30.258 & .000 & reject \\
\hline F5 & $\begin{array}{c}\text { Collaboration of } \\
\text { resource }\end{array}$ & 291 & 1.80 & .840 & -24.367 & .000 & reject \\
\hline
\end{tabular}

